\title{
Expression Analysis of the Caspase 10 from Olive Flounder (Paralichthys olivaceus) against Viral Hemorrhagic Septicemia Virus (VHSV) Challenge
}

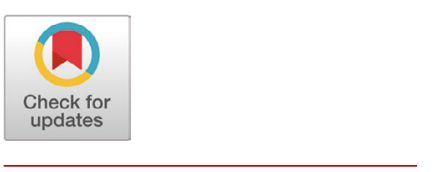

Received: June 19, 2020

Revised: July 15, 2020

Accepted: September 4, 2020

${ }^{+}$Corresponding author

Dain Lee

Genetics and Breeding Research Center, National Institute of Fisheries Science,

Geoje 53334, Korea.

Tel: +82-55-639-5813

Fax: +82-55-639-5809

E-mail: gene419@korea.kr

Copyright $\odot 2020$ The Korean Society of Developmental Biology.

This is an Open Access article distributed under the terms of the Creative Commons Attribution Non-Commercial License (http://creativecommons.org/licenses/ by-nc/4.0/) which permits unrestricted non-commercial use, distribution, and reproduction in any medium, provided the original work is properly cited.

ORCID

Kyung-Hee Kim

https://orcid.org/0000-0002-8162-3255

Sanghyun Lee

https://orcid.org/0000-0002-5725-666X Hyo Sun Jung

https://orcid.org/0000-0001-8690-2408 Julan Kim

https://orcid.org/0000-0003-1964-9486 Jong-Won Park

https://orcid.org/0000-0001-8188-7632 Choul-Ji Park

https://orcid.org/0000-0001-8448-6957 Hyejin Kim

https://orcid.org/0000-0003-3853-0034

Woo-Jin Kim

https://orcid.org/0000-0002-0921-2312

Dain Lee

https://orcid.org/0000-0002-5675-8000

Conflict of interests

The authors declare no potential conflict
Kyung-Hee Kim, Sanghyun Lee, Hyo Sun Jung, Julan Kim, Jong-Won Park, Choul-Ji Park, Hyejin Kim, Woo-Jin Kim, and ${ }^{\dagger}$ Dain Lee

Genetics and Breeding Research Center, National Institute of Fisheries Science, Geoje 53334, Korea

\section{Abstract}

The caspase10 encodes an initiating caspase that plays an important role in the maintaining the cellular homeostasis by regulating the steps involved in the immune response and cell death. We investigated the expression of caspase10 during the different developmental stages and in olive flounder tissues. Caspase10 increased in the late stage of the formation of immune tissue, and high expression was observed in the gills, kidney, skin, and spleen. The current study analyzed the expressional changes of caspase10 in olive flounder infected with viral hemorrhagic septicemia virus (VHSV). One of the major causes of mass mortality, VHSV infection in olive flounder attributes to significant expression of caspase10 in the gills, spleen, skin, and kidneys. The results indicate a close association of caspase10 expression with the immune response to VHSV infection in olive flounder. The observations could form the basis data for exploration of other fish immune system.

Keywords: Olive flounder Paralichthys olivaceus, Gene expression, Caspase10, Viral hemorrhagic septicemia virus (VHSV)

\section{INTRODUCTION}

The olive flounder is a flatfish belonging to the Pleuronectiformes order and Paralichthyidae family. It is an economically important marine organism that accounts for $40 \%$ of the marine fish farming (Bai et al., 2010). However, culturing olive flounder is subjected to multiple challenges owing to the various diseases and poor breeding environments (Kim et al., 2003; Kim et al., 2009). One notable challenge has been the damage caused by viral hemorrhagic septicemia virus (VHSV) infection. Every year in the East and South Sea waters, VHSV largely infects olive flounder and other wild fishes as well. The infection occurs even during winter and spring, when the water temperatures are low. The most common visible changes observed in an infected fish are body color blackening, abdominal distension, and hernia. Gill fading during dissection and clear ascites in the abdomen are also characteristic of VHSV infected fishes (kim et al., 2009; Duesund et al., 2010).

Caspase is a type of cysteine proteolytic enzyme that plays an important role in various stages of cell death, such as apoptosis, necrosis, and inflammatory reactions (Thornberry \& Lazebnik, 1998; Grutter, 
of interest.

Acknowledgements

This work was supported by a grant from the National Institute of Fisheries Science (R2020001).

Authors' contributions Conceptualization: Kim KH, Lee D.

Data curation: Kim WJ.

Formal analysis: Kim KH, Lee S.

Methodology: Park JW, Park CJ.

Software: Jung HS, Kim J.

Validation: $\mathrm{Kim} \mathrm{KH}$, Kim H.

Investigation: Kim KH, Lee S.

Writing - original draft: Kim KH.

Writing - review \& editing: Kim KH, Lee D.

Ethics approval

This article has been approved by IACUC by the Animal Experimental Ethics Committee (2020-NIFS-IACUC-17)
2000). According to the primary functions, caspase can be classified into apoptotic caspases (caspase $2,3,6,7,8,9$, and 10) and inflammatory caspases (caspase 1, 4, 5, 11, 12, and 13) (Earnshaw et al., 1999; Galluzzi et al., 2016). Apoptotic caspases can be further classified as initiator caspases (caspase 2, 8, 9, and 10) and executioner caspases (caspase 3,6, and 7). Initiator caspases are located upstream in the caspase signaling cascade and are responsible for receiving and transmitting the apoptotic signals from the mitochondria or death receptors to the effector caspases (Vincenz \& Dixit, 1997; Pan et al., 1998). Executioner caspases further transmits the apoptosis-inducing signals from the initiator caspases to activate a variety of apoptosis-mediating enzymes, such as the deoxyribonuclease (DNase) and protease (Liu et al., 1997).

Caspase10 encoded by the caspase10 gene belongs to the cysteine-aspartic acid protease family and is responsible for maintaining cellular homeostasis by regulating the immune response and apoptosis (Yan et al., 2012; Kumari et al., 2019). Caspase10 acts on the effector procaspase and thereby cleaves it into its biologically active form that plays an important role in the Fas ligand mediated apoptosis (Stennicke et al., 1998; Ekchariyawat et al., 2012). Caspase10 is involved in the elimination of $\mathrm{T}$ cells in response to an autogenous antigen and thus results in an immune system disorder characterized by reduced sensitivity to Fas ligand mediated apoptosis (Shin et al., 2002).

Currently, studies have reported the presence of caspase family in Atlantic salmon (Salmo salar), channel catfish (Ictalurus punctatus), goldfish (Carassius auratus), medaka (Oryzias latipes), orangespotted grouper (Epinephelus coioides), rainbow trout (Oncorbynchus mykiss), rohu (Labeo rohita), sea bass (Dicentrarchus labrax) and zebrafish (Daniorerio) (Naruse et al., 2000; Laing et al., 2001; Yabu et al., 2001; Long et al., 2004; Amali et al., 2006; Chakraborty et al., 2006; Takle et al., 2006; Reis et al., 2007a; Reis et al., 2007b; Arockiaraj et al., 2013; Allan et al., 2020; Samanta et al., 2020; Zhang et al., 2020). Caspase10 has been specifically reported in olive flounder, black rockfish (Sebastes schlegelii), and snakehead murrel (Channa striatus) (Kurobe et al., 2007; Elvitigala et al., 2015; Cho et al., 2016). There is limited information on the immune system regulation mediated by caspase 10 in response to viral infection in the fishes. Therefore, in this study, we investigated the immune response of caspase10 to VHSV infection in olive flounder, one of the major causes of mass mortality.

\section{MATERIALS AND METHODS}

\section{Fish culture and tissue sampling}

The olive flounders used in the experiment were bred at $19 \pm 1^{\circ} \mathrm{C}$ in a 3-ton flow-through tank using a $15 \mathrm{~h}$ photoperiod and $9 \mathrm{~h}$ dark cycle, at the Genetics and Breeding Research Center, National Institute of Fisheries Science (NIFS). In order to analyze the expression of caspase10 during the different developmental stages of olive flounder, samples from 0 to 40 days after hatching (DAH) were placed in a TRI-Solution ${ }^{\text {TM }}$ (TS200-001, Bio Science Technology, Daegu, and Korea) and stored at $-80^{\circ} \mathrm{C}$ until ribonucleic acid (RNA) isolation. To analyze the tissue-specific expression of caspase10, various tissues were extracted from a healthy 8-month-old olive flounder (total length approximately $30 \mathrm{~cm}$ ) and stored at $-80^{\circ} \mathrm{C}$ until RNA isolation. To minimize the stress of olive flounder, anesthesia was performed using tricaine methanesulfonate (MS-222) (Sigma-Aldrich, St. Louis, MO, USA) at a concentration of 150 ppm, before the experiment (Noh et al., 2017).

\section{VHSV artificial infection}

The VHSV artificial infection test was conducted using healthy 8-months-old olive flounder (total length approximately $30 \mathrm{~cm}$ ). The fish were made to fast on the day before and on the day of 
artificial infection test after being placed in a 3-ton flow-through tank with water at a temperature of $19 \pm 1^{\circ} \mathrm{C}$. A breeding condition of $15 \mathrm{~h}$ photoperiod and a $9 \mathrm{~h}$ dark cycle was maintained. The control group was inoculated with $100 \mu \mathrm{L}$ of $1 \mathrm{X}$ phosphate buffered saline (PBS), while the experimental group was inoculated with $10^{5}$ median tissue culture infectious dose $\left(\mathrm{TCID}_{50}\right)$ of VHSV. The kidney, gill, skin, and spleen were sampled every $0,1,3,6,9,12$, and $18 \mathrm{~h}$ for the first five consecutive days after inoculation and storage at $-80^{\circ} \mathrm{C}$ until RNA isolation. To minimize the stress of olive flounder, anesthesia was performed using MS-222 at a concentration of $150 \mathrm{ppm}$, before the experiment (Noh et al., 2017).

\section{RNA extraction and quantitative reverse-transcription polymerase chain reaction (qRT- PCR) analysis}

Total RNA was extracted using the same amount of sample by modifying the protocol of the TRI-Solution $^{\mathrm{TM}}$. The extracted RNA was decontaminated for genomic DNA using DNase-I. Total RNA was spectrophotometrically (Eon ${ }^{\mathrm{TM}}$ Microplate Spectrophotometer, BioTek, Winooski, VT, USA) evaluated by the ratio of the absorbance at 260 and $280 \mathrm{~nm}$ (A260/280) and 260 and 230 $\mathrm{nm}(\mathrm{A} 260 / 230)$. Total RNA was then used for the synthesis of complementary DNA (cDNA) using oligo (dT)18 primer and Transcriptor First Strand cDNA Synthesis Kit (Roche, Mannheim, Germany). Quantitative reverse-transcription polymerase chain reaction (qRT-PCR) was performed using $100 \mathrm{ng} / \mu \mathrm{L}$ of cDNA under the following process conditions: initial denaturation at $95^{\circ} \mathrm{C}$ for $20 \mathrm{~s}$, annealing at $58^{\circ} \mathrm{C}$ for $30 \mathrm{~s}$ and elongation at $60^{\circ} \mathrm{C}$ for $30 \mathrm{~s}$. The final dissociation marked the completion of the qRT-PCR reaction. The primers used for the qRT-PCR analysis were caspase10 primer (Gene bank, AB247499.1) and the 18S rRNA primer (Gene bank, EF126037.1). $18 \mathrm{~S}$ rRNA was used as the internal standard control, and the expression level for 18S rRNA was quantified using the $2^{-\Delta \Delta C t}$ method (Pfaffl, 2001). In addition, an $18 \mathrm{~S}$ rRNA and caspase10 primer of olive flounder was designed using the Primer3 program (Rozen \& Skaletsky, 2000). The primers used for the analysis were as follows: caspase10 forward (5'-GCACATGGACATCCTGAGTG-3') and caspase10 reverse (5'-AGGCTGCTCATTTCACTGCT-3'), 18S rRNA forward (5'-ATGGCCGTTCTTAGTTGGTG-3'), and 18S rRNA reverse (5'-CACACGTGATCCAG TCAGT-3').

\section{Statistical analysis}

All experiments were performed in triplicate for enhanced accuracy. The data were expressed as mean \pm SE. Statistical analysis of the data was performed using the statistical software package R-3.0.1 (Okorie et al., 2013). Significant differences in the data values were confirmed using the oneway analysis of variance (ANOVA). The significance test of expression among the individuals was conducted using the Duncan's least significant range (LSR) test, when $p<0.05$.

\section{RESULTS}

\section{Expression analysis of caspase 10 during the initial developmental stages}

The innate immune response of caspase 10 was investigated through the expression analysis of caspase10 during the initial developmental stages of olive flounder to $40 \mathrm{DAH}$. Quantitative analysis was performed using qRT-PCR. Using gene-specific primer for caspase10, the amount of mRNA expression in each step was calculated using the $18 \mathrm{~S}$ rRNA. The results were compared with eggs (the value set to 1 ) to investigate the expression during different developmental stages. The expression of caspase10 compared to that in eggs (1.0-fold) was low until 9 days (0.7-fold) 


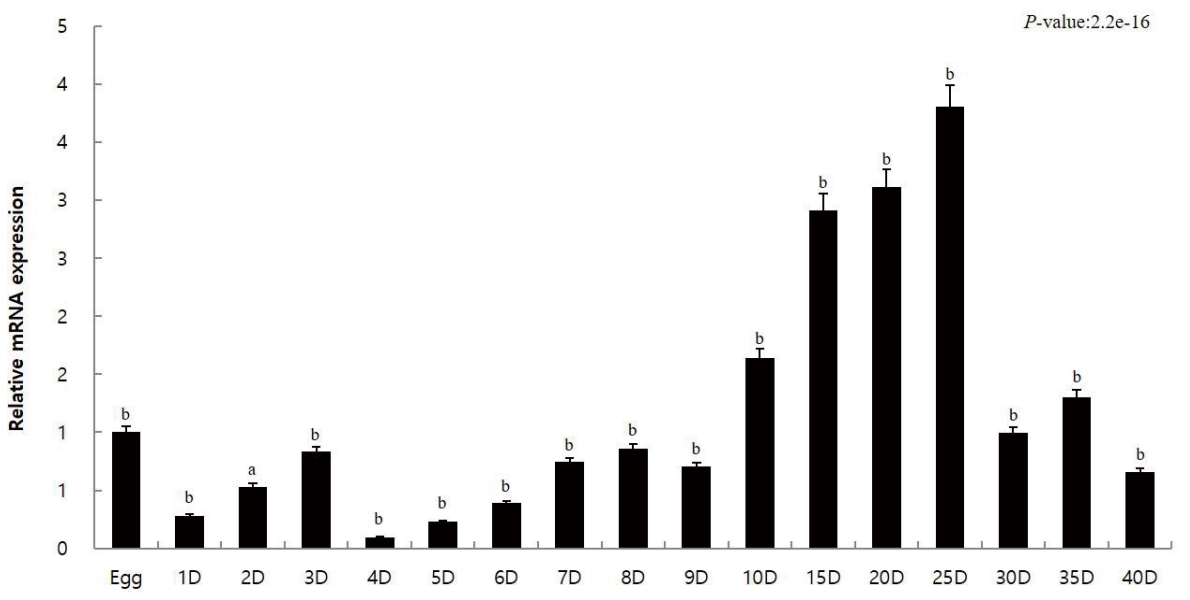

Fig. 1. Expression of caspase10 during the different developmental stages of olive flounder. The mRNA expression of caspase 10 was analyzed via qRT-PCR from fertilization though to 40 day old larvae. Each experiment was performed in triplicate and the expression levels of 18S rRNA and caspase 10 at the egg stage were set as 1. qRT-PCR, quantitative reverse-transcription polymerase chain reaction.

after hatching (Fig. 1). It gradually increased from day 10 (1.6-fold) and showed high expression on day 25 (3.8-fold) (Fig. 1). A dip in the expression profile of caspase10 was reported after day 25 (Fig. 1).

\section{Expression analysis of caspase 10 from various tissues}

In order to observe the expression of caspase10 in the different tissues of olive flounder, we extracted the brain, eye, fin, gill, intestine, kidney, liver, muscle, skin, spleen, and stomach tissues. The qRT-PCR analysis using gene-specific primer for caspase10 was performed to examine the tissuespecific expression of caspase10. The relative mRNA expression in each tissue was calculated using $18 \mathrm{~S}$ rRNA, and the same was compared with the expression within the brain (the value set to 1). Results revealed high expression of capsase10 in the kidney (2.0-fold), spleen (2.5-fold), and skin (3.3-fold) and the highest expression in the gills (5.3-fold) (Fig. 2). The expression of caspase10 was low in the liver (0.2-fold), stomach (0.4-fold), intestine (0.7-fold), muscle (0.8-fold), fin (1.0-fold),

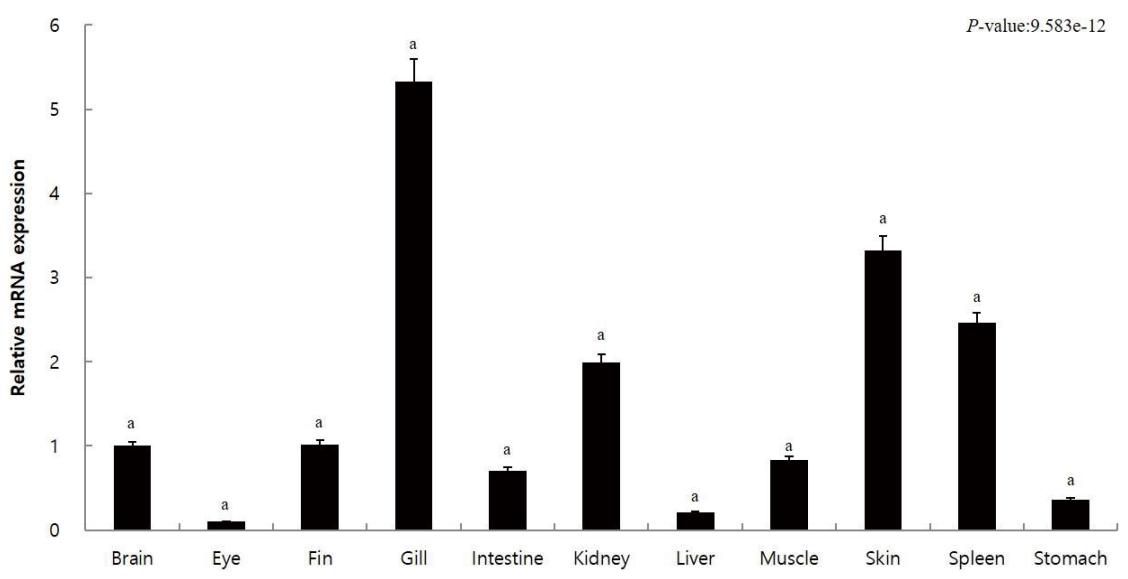

Fig. 2. Expression of caspase10 mRNA in various tissues of olive flounder. The expression of caspase 10 expression in various tissues was determined via qRT-PCR. Each experiment was performed in triplicate and the expression levels of $18 \mathrm{~S}$ rRNA and caspase 10 at the egg stage were set as 1. qRT-PCR, quantitative reverse-transcription polymerase chain reaction. 
and brain (1.0-fold), and the lowest in the eye (0.1-fold) (Fig. 2).

\section{Expression analysis of caspase 10 from VHSV challenge}

In order to study the role of caspase10 in the immune response to viral infection, caspase10 gene expression was examined over time in olive flounder artificially infected with VHSV. The relative mRNA expression for each hour was calculated using the reference gene, olive flounder $18 \mathrm{~S}$ rRNA, and the specific expression was examined by comparing the result with $0 \mathrm{~h}$ (the value set to 1), that is, the start time of infection. In the kidney and gills, caspase10 showed similar expression patterns. The expression increased from day 2 (kidney, 9.4-fold; gill, 6.2-fold) showing the highest expression on day 3 (kidney, 11.1-fold; gill, 7.9-fold) and then again decreased from day 4 (kidney, 8.4-fold; gill, 7.2-fold). In the skin, caspase10 did not show significant expression until 2 days (0.5fold) after hatching. After that, the expression increased on day 3 (4.9-fold) and day 4 (9.0-fold), and thereafter again decreased on the day 5 (1.9-fold). In the spleen, the expression of caspase10 gradually increased from day 1 (1.0-fold) and showed the highest expression on day 5 (4.0-fold).

\section{DISCUSSION}

The olive flounder is an economically important aquaculture fish species. However, in the recent years, disease causing infections have led to a significant damage of the fish species (Kim et al., 2009). Like most fishes, olive flounder lives in an aquatic environment from its egg stage and hence is exposed to many pathogens from the time of fry. In mammals, immune systems, such as the bone marrow and lymph nodes are less evolved, but they produce antibodies and destroy the microorganisms by the innate immune responses (Magnadottir, 2006). Therefore, in order to understand the innate immune response of olive flounder, we observed the tissue-specific expression of caspase10 during the different developmental stages of olive flounder, that is, from egg to day 40 after hatching.

The expression pattern of caspase10 was similar to that of eggs until day 9 after hatching, but the expression increased on day 10 and showed high expression on day 25 after hatching (Fig. 1). Day 28 after hatching marks the late metamorphosis in olive flounder (Kim, 2009). During this stage the stomach becomes enlarged, and the digestive tract develops into a structure similar to that of adult fish. The clear demarcation of the front, back, and rectum marks the transition to the fry or young stage. The changes that resemble olive flounder to an adult fish are accompanied by an increase in the caspase10 expression. However, the caspase10 expression decreased 25 DAH (Fig. 1). The variation in the caspase10 expression indicates that the expression is higher when the fry olive flounder enters the bottoming stage after the metamorphosis is completed, rather than in the early of metamorphosis. As a result, caspase10 is expected to be deeply involved in immune response of olive flounder, as during the late stages of development, the formation of the immune specific tissues is completed.

Fish gills, skin, and stomach are considered as the peripheral lymphoid tissues, and the kidneys and spleen are the main lymphoid tissues that proliferate and differentiate into lymphocytes (Sizemore et al., 1984; Zapata \& Cooper, 1990; Rombout et al., 1993; Petrie-Hanson L \& Ainsworth AJ, 2001; Langenau et al., 2004). These study revealed high caspase10 expression in the lymphoid tissues such as the gill, spleen, and kidney of olive flounder (Fig. 2). According to a previous report, high expression of caspase10 has been reported in the blood, gills, and spleen of stone rock black rockfish, in the gills and spleen of snakehead murrel, and in the white blood cells (WBC), gills, and spleen of olive flounder (Kurobe et al., 2007; Arockiaraj et al., 2013; Elvitigala et 

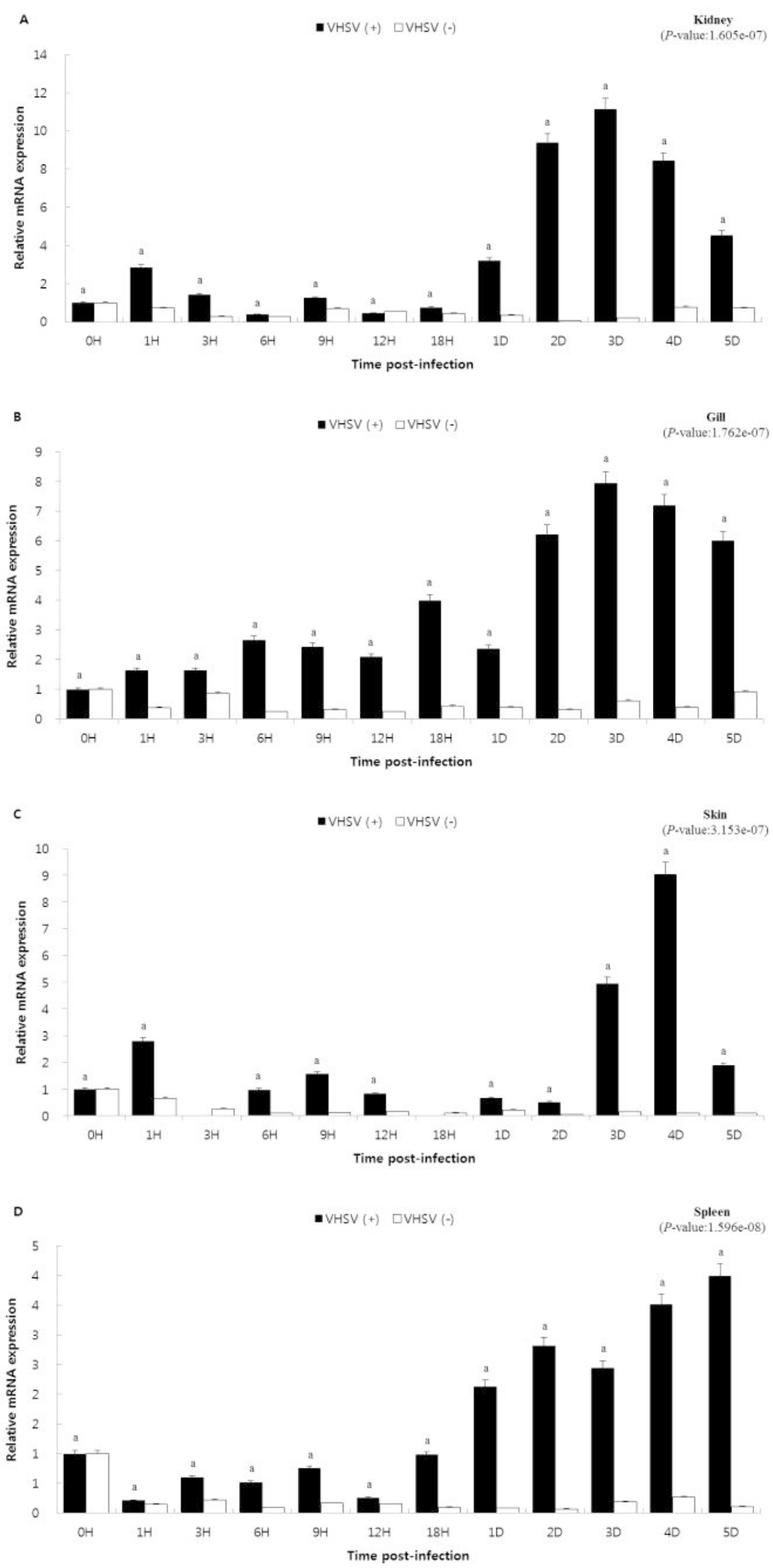

Fig. 3. Relative expression of caspase10 in kidney (A), gill (B), skin (C), and spleen (D) tissues of olive flounder within 5 days post-VHSV injection. Each experiment was performed in triplicate and the expression levels of $18 \mathrm{~S}$ rRNA and caspase 10 at $0 \mathrm{~h}$ were set as 1. 
al., 2015). From these results, it could be confirmed that despite the differences depending on the type of fish, most of them show high caspase10 expression in immune tissues.

Caspases, based on their primary functions are classified into inflammatory, initiator, and effector caspases. Caspase10 is an initiating caspase of the cysteine-aspartic acid protease family and plays an important role in regulating cell death or apoptosis. In this study, the expression of capase10 was observed in response to VHSV infection, one of the major causes of mass death of olive flounder. The kidney being an immune-related organ is rich in leukocytes and other immune cells. On VHSV infection, kidney exhibited no significant difference in caspase10 expression. However, a heightened expression was reported on day 3 which again decreased thereafter (Fig. 3A) (Uribe et al., 2011). A similar caspase10 expression pattern was observed in the gills and skin, which remains exposed to the aquatic environment and thus pose as the most convenient invasion route for numerous microorganisms (Fig. 3B and 3C) (Kim, 2012). In the case of spleen, the caspase10 expression gradually increased over time and showed the highest expression on day 5 (Fig. 3D) (Sizemore et al., 1984; Rombout et al., 1993). Therefore, it can be expected that the high expression of caspase10 in the immune system-related tissues appropriately contributes to cell death during viral infection. Interpreting the results of the study, it could be stated that the expression of caspase10 is not just limited to viral invasion, but gradually increases as the disease becomes severe, promoting the induction of apoptosis and subsequent killing of the infected cells. In this study, the expression of caspase 10 was analyzed to study the immune system of fish. The expression of caspase10 under viral infection suggested the possibility of killing infected cells in an immunerelated tissue, which otherwise could be the cause of death in a virus-infected fish. These results are expected to be useful as the preliminary data for studying the immune responses in fish.

\section{REFERENCES}

Allan ERO, Dores CB, Nelson ER, Habibi HR (2020) Acute exposure to physiological doses of triiodothyronine does not induce gonadal caspase 3 activity in goldfish in vitro. Gen Comp Endocrinol 289:113382.

Amali AA, Rekha RD, Lin CJ, Wang WL, Gong HY, Her GM (2006) Thioacetamide induced liver damage in zebrafish embryo as a disease model for steatohepatitis. J Biomed Sci 13:225232.

Arockiaraj J, Gnanam AJ, Muthukrishnan D, Pasupuleti M, Milton J, Singh A (2013) An upstream initiator caspase 10 of snakehead murrel Channa striatus, containing DED, p20 and p10 subunits: Molecular cloning, gene expression and proteolytic activity. Fish Shellfish Immunol 34:505-513.

Bai SC, Lee SH (2010) Culture of olive flounder: Korean perspective. In Daniels HV, Watanabe WO (eds), Practical Flatfish Culture and Stock Enhancement. Wiley-Blackwell, New York, NY, pp 156-168.

Chakraborty C, Nandi SS, Sinha S, Gera VK (2006) Zebrafish caspase-3: Molecular cloning, characterization, crystallization and phylogenetic analysis. Protein Pept Lett 13:633e40.

Cho HK, Kim J, Moon JY, Nam BH, Kim YO, Kim WJ, Park JY, An CM, Cheong J, Kong HJ (2016) Microarray analysis of gene expression in olive flounder liver infected with viral haemorrhagic septicaemia virus (VHSV). Fish Shellfish Immunol 49:66-78.

Duesund H, Nylund S, Watanabe K, Ottem KF, Nylund A (2010) Characterization of a VHS virus genotype III isolated from rainbow trout (Oncorbychus mykiss) at a marine site on the west coast of Norway. Virol J 7:19. 
Earnshaw WC, Martins LM, Kaufmann SH (1999) Mammalian caspases: Structure, activation, substrates, and functions during apoptosis. Annu Rev Biochem 68:383-424.

Ekchariyawat P, Thitithanyanont A, Sirisinha S, Utaisincharoen P (2012) Apoptosis induced by avian $\mathrm{H} 5 \mathrm{~N} 1$ virus in human monocyte-derived macrophages involves TRAIL-inducing caspase-10 activation. Innate Immunity 18:390-397.

Elvitigala DAS, Whang I, Jung HB, Lim BS, Nam BH, Lee J (2015) Molecular delineation of a caspase 10 homolog from black rockfish (Sebastes schlegelii) and its transcriptional regulation in response to pathogenic stress. Gene 570:288-294.

Galluzzi L, López-Soto A, Kumar S, Kroemer G (2016) Caspases connect cell-death signaling to organismal homeostasis. Immunity 44:221-231.

Grutter MG (2000) Caspases: Key players in programmed cell death. Curr Opin Struct Biol 10:649-655.

Kim EG (2012) Molecular characterization, expression analysis and biological activity of two chemokines from rock bream (Oplegnathus fasciatus). M.S. Thesis, Gyeongsang National University, Jinju, Korea.

Kim KS (2009) Study on early development and metmorphosis of Paralichthys olivaceus. Ph.D. Thesis, Chonnam National University, Gwangju, Korea.

Kim SM, Lee JI, Hong MJ, Park HS, Park SI (2003) Genetic relationship of the VHSV (viral hemorrhagic septicemia virus) isolated from cultured olive flounder, Paralichthys olivaceus in Korea.J Fish Pathology 16:1-12.

Kim WS, Kim SR, Kim DW, Kim JO, Park MA, Kitamura SI, Kim DH, Han HJ,Jung SJ, Oh MJ (2009) An outbreak of VHSV (viral hemorrhagic septicemia virus) infection in farmed olive flounder Paralichthys olivaceus in Korea. Aquaculture 296:165-168.

Kong HJ, Hong GE, Kim WJ, Kim YO, Nam BH, Lee CH, Do JW, Lee JH, Lee SJ, Kim KK (2009) Cloning and characterization of hypusine-containing protein eIF5A from the olive flounder Paralichthys olivaceus. Comp Biochem Physiol 153:281-287.

Kumari R, Deshmukh RS, Das S (2019) Caspase-10 inhibits ATP-citrate lyase-mediated metabolic and epigenetic reprogramming to suppress tumorigenesis. Nature Commun 10:1-15.

Kurobe T, Hirono I, Kondo H, Yamashita M, Aoki T (2007) Molecular cloning, expression, and functional analysis of caspase-10 from Japanese flounder Paralichthys olivaceus. Fish Shellfish Immunol 23:1266-1274.

Laing KJ Holland J Bonilla S Cunningham C Secombes CJ (2001) Cloning and sequencing of caspase 6 in rainbow trout, Oncorbynchus mykiss, and analysis of its expression under conditions known to induce apoptosis. Dev Comp Immunol 25:303-312.

Langenau DM, Ferrando AA, Traver D, Kutok JL, Hezel JP, Kanki JP (2004) In vivo tracking of T cell development, ablation, and engraftment in transgenic zebrafish. Proc Natl Acad Sci USA 101:7369-7374.

Liu X, Zou H, Slaughter C, Wang X (1997) DFF a heterodimeric protein that functions downstream of caspase-3 to trigger DNA fragmentation during apoptosis. Cell 89:175-184.

Long S, Wilson M, Bengten E, Clem LW, Miller NW, Chinchar VG (2004) Identification and characterization of a FasL-like protein and cDNAs encoding the channel catfish deathinducing signaling complex. Immunogenetics 56:518-530.

Naruse K, Fukamachi S, Mitani H, Kondo M, Matsuoka T, Kondo S (2000) A detailed linkage map of medaka, Oryzias latipes: Comparative genomics and genome evolution. Genetics 154:1773-1784.

Noh GE, Kim WJ, Kim HC, Park CJ, Park JW (2017) Daily rhythms and effect of short-term starvation on the of health parameters in olive flounder Paralichthys olivaceus. Korean J Fish 
Aquat Sci 50:534-540.

Okorie OE, Bae JY, Kim KW, Son MH, Kim JW, Bai SC (2013) Optimum feeding rates in juvenile olive flounder, Paralichthys olivaceus, at the optimum rearing temperature. Aquacult Nutr 19:267-277.

Pan G, Humke EW, Dixit VM (1998) Activation of caspases triggered by cytochrome c in vitro. FEBS Lett 426:151-154.

Petrie-Hanson L, Ainsworth AJ (2001) Ontogeny of channel catfish lymphoid organs. Vet Immunol Immunopathol 81:113-127.

Pfaffl MW (2001) A new mathematical model for relative quantification in real-time RT-PCR. Nucleic Acids Res 29:e45.

Reis MI, do Vale A, Pinto C, Nascimento DS, Costa-Ramos C, Silva DS (2007a) First molecular cloning and characterisation of caspase-9 gene in fish and its involvement in a Gram negative septicaemia. Mol Immunol 44:1754-1764.

Reis MI, Nascimento DS, do Vale A, Silva MT, Dos Santos NM (2007b) Molecular cloning and characterisation of sea bass (Dicentrarchus labrax L.) caspase-3 gene. Mol Immunol 44:774783.

Rombout JH, Taverne-Thiele AJ, Villena MI (1993) The gut-associated lymphoid tissue (GALT) of carp (Cyprinus carpio): An immunocytochemical analysis. Dev Comp Immunol 17:55-66.

Rozen S, Skaletsky HJ (2000) Primer3 on the WWW for general users and for biologist programmers. In: Misener S, Krawetz SA (eds), Bioinformatics Methods and Protocols: Methods in Molecular Biology. Humana Press, Totowa, NJ, pp 365-386.

Samanta M, Giri AK, Paichha M, Choudhary P, Saha A (2020) Caspase-8 in Labeo rohita is evolutionary conserved and is activated in Aeromonas hydrophila and Edwardsiella tarda infection and rhabdovirus vaccination.J Basic Appl Zool 81:1-14.

Shin MS, Kim HS, Kang CS, Park WS, Kim SY, Lee SN, Lee JH, Park JY, Jang JJ, Kim CW, Kim SH, Lee JY, Yoo NJ, Lee SH (2002) Inactivating mutations of CASP10 gene in non-Hodgkin lymphomas. Blood 99:4094-4099.

Sizemore RC, Miller NW, Cuchens MA, Lobb CJ, Clem LW (1984) Phylogeny of lymphocyte heterogeneity: The cellular requirements for in vitro mitogenic responses of channel catfish leukocytes. J Immunol 133:2920-2924.

Stennicke HR, Jurgensmeier JM, Shin H, Deveraux Q, Wolf BB, Yang X, Zhou Q, Ellerby HM, Ellerby LM, Bredesen D, Green DR, Reed JC, Froelich CJ, Salvesen GS (1998) Pro-caspase-3 is a major physiologic target of caspase-8. J Biol Chem 273:27084-27090.

Takle H, McLeod A, Andersen O (2006) Cloning and characterization of the executioner caspases 3, 6, 7 and Hsp70 in hyperthermic Atlantic salmon (Salmo salar) embryos. Comp Biochem Physiol B Biochem Mol Biol 144:188-198.

Thornberry NA, Lazebnik Y (1998) Caspases: Enemies within. Science 281:1312-1316.

Uribe C, Folch H, Enriquez R, Moran G (2011) Innate and adaptive immunity in teleost fish: A review. Vet Med 56:486-503.

Vincenz C, Dixit VM (1997) Fas-associated death domain protein interleukin-1beta-converting enzyme 2 (FLICE2), an ICE/Ced-3 homologue, is proximally involved in CD95- and p55mediated death signaling.J Biol Chem 272:6578-6583.

Yabu T, Kishi S, Okazaki T, Yamashita M (2001) Characterization of zebrafish caspase-3 and induction of apoptosis through ceramide generation in fish fathead minnow tailbud cells and zebrafish embryo. Biochem J 360:39-47.

Yan S, Li YZ, Zhu JW, Liu CL, Wang P, Liu YL (2012) Role of CASP-10 gene polymorphisms in cancer susceptibility: A huge review and meta-analysis. Genet Mol Res 11:3998-4007. 
Zapata AG, Cooper EL (1990) The Immune System: Comparative Histophysiology. John Wiley and Sons, Chichester, UK, pp 232-268.

Zhang X, Liu Z, Li C, Zhang Y, Wang L, Wei J, Qin Q (2020) Characterization of orange-spotted grouper (Epinephelus coioides) ASC and caspase-1 involved in extracellular ATP-mediated immune signaling in fish. Fish Shellfish Immunol 97:58-71. 